\title{
作問事例を用いて数学文章題を生成するシステム の実現と評価
}

\section{Construction and Evaluation of a System that Generates Mathemat- ical Word Problems Using Cases of Problem generation}

\author{
$\begin{array}{ll}\text { 小島 一晃 } & \text { 名古屋大学 大学院人間情報学研究科 } \\ \text { KOJIMA Kazuaki } & \text { Graduate School of Human Informatics, Nagoya University }\end{array}$ \\ koj@cog.human.nagoya-u.ac.jp,http://www.cog.human.nagoya-u.ac.jp/ koj/ \\ 三輪 和久 \\ 名古屋大学 大学院情報科学研究科 \\ Graduate School of Information Science, Nagoya University \\ miwa@cog.human.nagoya-u.ac.jp, http://www.cog.human.nagoya-u.ac.jp/ miwa/
}

keywords: mathematical learning, word problems, automatic problem generation, problem generation episodes

\section{Summary}

In mathematical learning, it is important to give learners a number of problems that have various features in both of surface problem situations and deep mathematical structures. In this study, we implement a system that generates various word problems by using problem-generation episodes. Each problemgeneration episode is knowledge comprising a base example problem and a new analogical instance, which is regarded as a past case where the analogical instance was generated from the example problem. Our system can generate various problems by applying the problem-generation episodes to initial problems stored in the system. In this paper, we describe our approach to generate mathematical word-problems, and perform experimental evaluations to verify whether or not our system can expand the variety of problems. The results of the experiments indicated that our system can appropriately expand the variety. We also found that it needs interactions with a knowledgeable user.

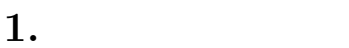

数学学習は, 教師が例題によって解法の教示を行い, 学 習者は关の例題の類題を数多く解決する練習を行うとい う方法で進められる.学習者が学習を行う上では通常，多 数の問題が必要となり, 教師は複数の教科書や問題集を 利用して問題を用意している.このような背景から，学 習者が学習を行うための問題を供給することは, 学習支 援における重要な課題であると考えられる .

ところで, 数学学習で使用される問題には, 問題文に 「買物」や「乗物での移動」といった問題状況を持つ文章 題がある . 文章題では，解法構造だけでなく問題状況も， 学習者の学習において考慮すべき重要な情報である．

このことに関しては, 初学者の問題解決は問題状況の ような問題文の表層的特徵に強く影響されることか確認 されており [Chi 81, Novick 88], 問題状況は異なるが解 法は同一の問題など，樣々な問題を与えて比較させるこ とが重要であるという指摘がされている . 問題を比較し て類似性の判断を行うことは, 問題解決において重要な 特徵への注目を促進し, 問題解決を成功に導くことが心
理学的な実験によって示されている [Gick 83]．この知見 を用いて English は, 文章題の学習において, 問題状況 と解法をコントロールした問題を生徒に提示し, 光れら を比較する訓練を行わせることで, 生徒の文章題に対す る理解か改善したことを報告している [English 97] . こ の他にも，多くの実験的な知見から複数の問題間の比較 を行う訓練の必要性が示唆されている [寺尾 98]. 数学学 習において，問題状況と解法をコントロールして問題を 出題することは, 学習者の深い問題理解を導く上で有効 であり，また，問題間の比較による学習を提供する上で 必要となる。

このような背景から，例題に基づく類題解決による学 習を支援対象として想定した場合，問題状況と解法の 2 つの属性において構造化された問題のデータベースを提 供することには，重要な意味がある．さらに，2つの属性 をコントロールして問題の提示を行う上でも，この属性 において多樣性を持つ問題は必須となる．とのため，問 題状況と解法において多樣な問題を生成し，問題のデー タベースを構筑・提供することが可能な機能の実現か望 まれる.このようなデータベースがあれば, 例えば, 学習 
者が学習した例題に対し, 同一の解法を持つが問題状況 が異なる問題と，光の逆に問題状況が同一であるが解法 が異なる問題とを与えるといったことが可能になり，学 習者に例題とこれらの問題とを比較させ，どのような点 か類似しているか , 例題はどちらの問題の解決に貢献す るかといった点の検討を行わせることで, 問題解決にお いて重要な特徵への注目を促進することができると考え られる.しかし，問題状況のような情報を扱うためには， 常識知識や自然言語処理といった課題を克服する必要が あるため，文章題を自動生成する機能の実現は，極めて 困難である .

数学の問題を生成するシステムは, これまでにも樣々 なものが開発されている、例えば，MathTeX[1]は，高 校数学の計算問題と乥の解答を自動的に生成して, $\mathrm{TeX}$ 形式で出力するツールである . [白田 04] は, 経済最適化 問題の問題領域において, 条件や未知数といった問題の 定義情報が与えられると，乥の情報から Web 教材を自動 的に生成するシステムを構築している.[金西 03] は，事 前に与えられた問題生成に関する知識に基づき，基本情 報技術者試験の数量関係の問題構造と解, 問題文を生成 するシステムを実装している.こうしたシステムは，問 題の供給を行ったり，具体的に教材を用意する手間を軽 減することを目的としているが, 問題文の問題状況のよ うな情報が重要ではない問題領域を扱っている.

一方，文章題に関しては, 計算機処理可能な問題の特 徵記述を与える一連の研究が, 平嶋らによって行われて いる.これらの研究においては, 問題を定式化する過程 のモデルにより，問題の表層構造と解法構造を表現する 特徵記述が提案されており [平嶋 92, Hirashima 94] , 数 学の文章題や力学などの領域において, 補助問題の定式 化 [平嶋 95] や問題の整列 [Hirashima 94]，学習者による 作問の診断 [中野 00], 問題のオーサリング支援環境 [平 嶋 01] などか実現されている．また，問題の自動生成に ついても, 問題の簡単化という観点からの試みが行われ ている [Hirashima 94] .さらに , [高野 03] のWBT シ ステムは鶴亀算型の文章題の自動生成を行うが, システ ムに用意された限られた解法と問題状況を持つ問題を生 成するのみに留まっている．このことからも，問題状況 と解法において多樣な問題を生成するシステムの実現が 望まれる .

本研究では, 数学の文章題を対象とし,「問題状況」と 「解法」において多樣な問題を生成するためのシステムの 実装を行う . 本システムの目標は,「問題集の問題などを 登録し，登録された問題から新しい問題を生成して，問 題のバリエーションを増殖する」ことである.自然言語処 理や常識知識などの問題については，1. 作問を事例化し， 事例を利用して問題を生成できるような仕組みを実現す る，2. 教師ユーザとのインタラクションにより問題生成 を行う，という方法によって克服・回避するアプローチ を採用する．作問の事例化とは，ある例題に対し，关の
類題が生成された時, この 2 つの問題の間で結ぶことが できる関係を事例とすることであり，問題を事例と捉え ると，作問の事例はメタ事例にあたる．本研究では，こ のような作問の事例を「作問エピソード」と呼ぶ .

\section{2. 文章題生成システム}

本研究で実装を行ったシステムは, 数学の問題データ を蓄積し，蓄積されている問題データを用いて新しい問 題を生成するシステムである. 本システムによる問題生 成では, 教師ユーザとのインタラクションを実行し, ユー ザか問題データの登録を行った上で，同時に常識知識も ユーザが補間することを前提とする．本研究で目標とす るのは, 問題状況と解法において多樣な問題を生成する システムの実現である . 本システムは, ユーザとのインタ ラクションを通じて多樣な問題のデータベースを構築し， 学習者や学習支援システムへの教材コンテンツ供給を行 うことができると考えられる。しかし, 本研究で扱うの は問題の生成までであり, 具体的な学習支援や他システ ムとの連携の実現方法については, 今後の課題である .

本システムの問題対象領域には, 鶴亀算型の文章題と 光の類題を選択した.これは, 2 つのオブジェクトの数 量と属性値に関する情報から，二元一次方程式を用いて 解決する問題であり，中学校数学における「連立方程式 の応用」に含まれる . システムの実装は連立方程式の応 用という個別的な領域において行われたが，本研究で提 案する手法は，問題状況を表す問題文を持ち，方程式で 解決することが可能な文章題の問題領域であれば，一般 的に利用可能であると考えられる .

\section{$2 \cdot 1 \quad$ 問題生成の基本コンセプト}

本システムは, システムに登録されている問題データ から作問エピソードを構成し，これを用いて新しい問題 の生成を行う．先に述べたように，作問エピソードは作 問を事例化した知識であり，ある例題 baseに対して，光 の練習問題となる類題 newInstance が作成されたとする と，この 2 つの問題と，产れらの間の関係をデータとし て持つ事例である . 本システムはこの作問エピソードを 用いて，入力として与えられる問題 input に対し，作問 エピソードにおける base と newInstance の関係を適用 することで, 新しい問題 output の生成を行う.

図 1 に作問エピソードを用いた問題生成の概念図を示 す.图 1 において, 横軸は解法の特徵, 縦軸は問題状況の 特徵を表している．各座標 (A-1，A-2 など) は, 同一の 解法と同一の問題状況を持つ問題が属すカテゴリを表す ことになるが，このカテゴリをここでは「問題パターン」 と呼ぶことにする .今，A-1，B-1，A-2，A-3の4 つの問 題パターンに属する問題か事例として格納されていると仮 定する.乥して，A-1に属する一つの問題を base，B-1に 属する問題を newInstance として, 妥当な作問エピソー 


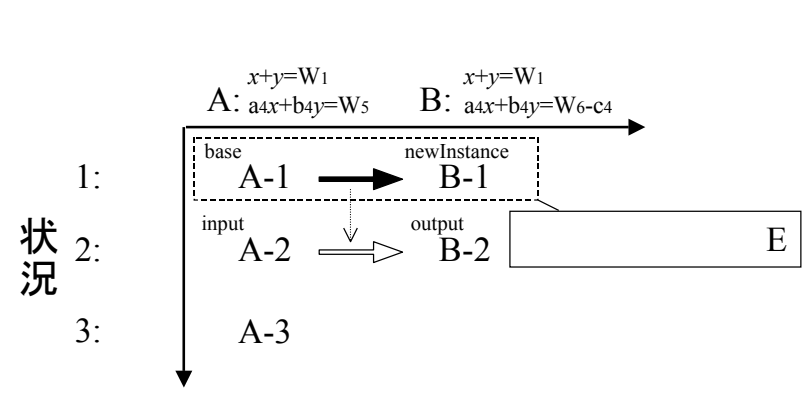

図 1 作問エピソードを用いた問題生成の概念図

ドEが抽出されたとする .この時, input として A-2の 問題にE を適用することが可能であったとすると，B-2の 問題が output として新たに生成される．つまり，本シス テムによる作問は,「base:newInstance=input:output」 という四項類推の形式によって input から output を生 成すること，ということができる．同樣に，E を用いて A-3 の問題から B-3 の問題を生成することができる . こ れにより, 新しく B-2，B-3 という，解法が同一で状況 が異なる問題が生成され, 問題パターンが 2 つ増加した ことになる.ここで, システムの実装においては, 妥当 な作問エピソードを構成できるのは, 問題状況が同一で ある base と newInstance のみであり，作問エピソード を適用できるのは, base と解法が同一である input のみ である，という制約を与えている。これにより，作問工 ピソードは置き換えてよい解法を base に，置き換えられ る解法を newInstance に事例的に持つ知識ということに なり，input は置き換えてよい解法を持つ問題のみに絞 られることになる．

[平嶋 01] では, ある問題の解法構造に対し，差分とな る概念や操作を与えることで, 新しい解法構造の問題を 作成する方法か採用されている．これに対し，本システ ムによる新しい問題 output の生成は, newInstance を 用いて構築される解法構造に, input の状況を当てはめ ることで行われる，従って，本システムは，input の解 法構造に差分を与えることによる問題の生成に留まらず， input とは解法が持つ基本的な構造が異なる問題も生成 することができる .

このコンセプトに基づき, 本システムでは問題から作 問エピソードを構成し，これを他の問題に適用する方法 によって, システムが持っている問題の初期セットから 新しい問題を生成し，問題のバリェーションを増殖する .

なお，本システムによる問題生成では，上述の通りに 新しい問題パターンの問題を生成する他に, A-1 に属す る base 以外の問題から B-1 に属する問題を生成する場 合，つまり，既に存在する問題パターンに属する問題を生 成する場合も考えられる．前者のような問題生成を「新 規生成」，後者を「変更生成」と呼ぶことにする．変更 生成によって生成されるのは, この場合, newInstance

$$
\text { 表 } 1 \text { 問題データの例 } 1
$$

問題文) 80 円の鉛筆と 120 円のボールペンをあわせて 8 本買つ たら、代金は７６０円になった。光れ何本買つたか。

解) 鉛筆を $x$ 本、ボールペンを $y$ 本とおくと、

$$
x+y=8
$$
$80 x+120 y=760$

よって、 $x=5, y=3$

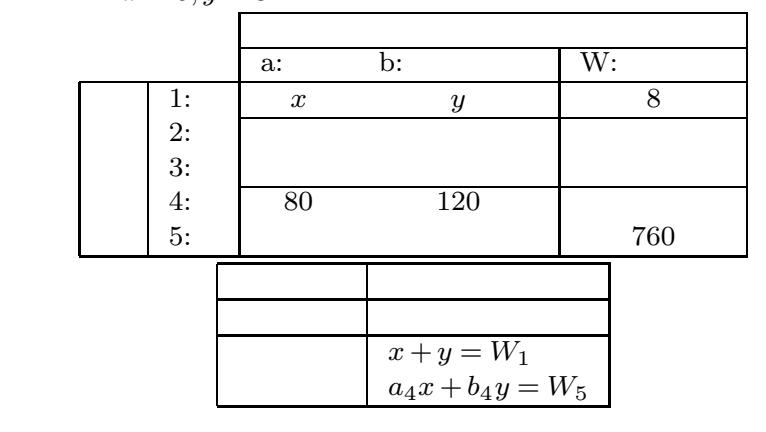

問題文テンプレート)

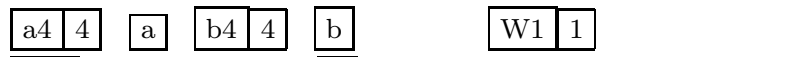
W5 5 5になった。 $\mathrm{a} と$ 古を关れ光れ何1買ったか。

と同じ問題パターンで, 問題文に登場するキーワード等 を変更したような問題ということになる .

\section{$2 \cdot 2$ 問 題 表 現}

本システムでは, 問題の特徵をテーブルの形式で表現 する. 問題データの例を表 1 に示す. 表 1 に含まれる数 值は方程式の係数であり(これを「数值パラメータ」と 呼ぶ）「オブジェクト」は問題に登場する鉛筆やボールペ ンといった問題要素,「プロパティ」は数値パラメータが 持つ助数詞や単位である. 問題データの基本構造は, 方

\section{表 2 問題データの例 2}

問題文) 80 円の鉛筆と 120 円のボールペンをあわせて 6 本と 5 ００円の筆箱を買つたら、代金は1060月になった。鉛筆とボー ルペンを弚れ光れ何本買ったか。

解) 鉛筆を $x$ 本、ボールペンを $y$ 本とおくと、 $x+y=6$

より、 $80 x+120 y+500=1060$

\begin{tabular}{|c|c|c|c|c|c|}
\hline & \multicolumn{4}{|c|}{ オブジェクト } \\
\hline & & a:鉛筆 & :ボールペン & $\overline{\mathrm{W} \text { : (全体) }}$ & c:筆箱 \\
\hline \multirow{5}{*}{$\begin{array}{l}\text { プ }^{\circ} \\
\text { ハ0 } \\
\text { パ } \\
\text { テ } \\
1\end{array}$} & \multirow{5}{*}{$\begin{array}{l}\text { 1:本 } \\
2: \\
3: \\
4: \text { 円 } \\
5: \text { 円 } \\
6: \text { 円 }\end{array}$} & $\bar{x}$ & $\bar{y}$ & 80 & \\
\hline & & & & & \\
\hline & & 80 & 120 & & 500 \\
\hline & & & & 560 & \\
\hline & & & & 1060 & \\
\hline & & 動該司 & 買う & & \\
\hline & & 状況 & 売買 & & \\
\hline & & 標準形 & $x+y=$ & & \\
\hline & & 追加操作 & $\frac{a_{4} x+b_{4}}{W_{5}=h}$ & $\frac{=W_{5}}{-c_{4}}$ & \\
\hline
\end{tabular}

$$
\begin{aligned}
& x+y=6 \\
& 80 x+120 y=560 \\
\text { よって、 } & x=4, y=2
\end{aligned}
$$

問題文テンプレート)

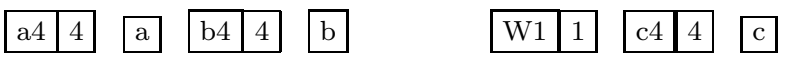

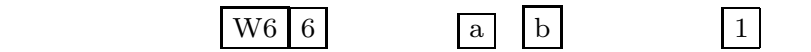
たか。 


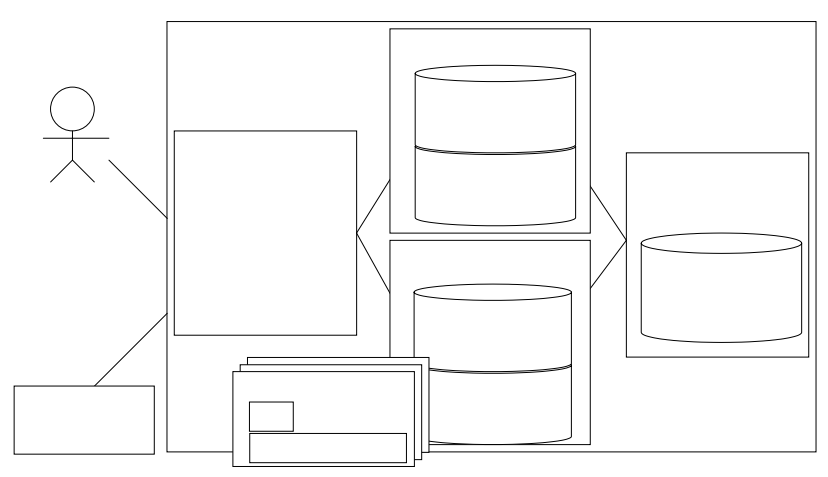

図 2 本システムの構成図

程式の数值パラメータとオブジェクト・プロパティの対 応表の形式で作成される.この他，問題文の場面を表す 動詞と問題状況, 解法の標準形, 数値パラメータを算出 する追加操作が必要な問題では, 弚の計算式といった情 報も問題データに含まれる．追加操作を含む問題の例を 表 2 に示す.このように，表 1 に示すような問題の基本 構造に対し，差分となる概念や演算を与えることで，表 2 に示す問題表現を与える方法は, 平嶋らのシステムに おいて用いられたものである [平嶋 01] .

また, 問題文中のオブジェクト, プロパティ, 数值パラ メータをスロットに置き換えた「問題文テンプレート」も 問題データ中に保持される. 問題文テンプレートは, シ ステムが問題を生成した際，弚の問題文を生成するため に利用される .

\section{$2 \cdot 3$ システムの構成}

本システムは, ユーザの入力する問題を解析して問題 データを生成する「入カインタフェース」, 問題生成に 利用する単語の知識を保持するための「辞書データベー ス」, 問題や作問エピソードを蓄積する「事例データベー ス」，作問エピソードの作成と問題生成を実行する「プ ロダクションエンジン」から成る.辞書データベースは， シソーラスを持つ「概念辞書」と，過去に文章題で使用 された単語や助数詞の知識を持つ「知識ベース」からな り，事例データベースは,「問題データベース」と「作問 エピソードデータベース」からなる．図 2 に本システム の構成図を示す .

ユーザとのインタラクションを通じてシステムが学習 するデータは, 知識ベースの「単語知識」と, 問題デー タベースの「問題データ」である．これらが蓄積されて いくことで , 作問エピソードのバリエーションが増加す ると同時に, オブジェクトとして使用可能な単語と, 問 題文テンプレートが増加し, システムが生成可能な問題 のバリエーションが増殖することが期待される .

なお , 本システムの実装にあたっては, 形態素解析ツー ルには茶鉒 $[2]$ ，概念辞書には分類語彙表 [3] を使用した．

\section{$2 \cdot 4$ 問題生成の実行手順}

以降では, 本システムが問題を生成するまでの手順を 具体的に説明する .

\section{$\S 1$ 問題データの登録}

本システムに問題を生成させるためには，まず最初に， ユーザが問題データの登録を行う.

ユーザが本システムに問題データを登録する際は, 問 題の問題文と解法式をテキスト形式で入力する . 本シス テムはまず最初に, 解法式の解析を行い, 問題データの 構造を理解するとともに, 解法式の数値パラメータを抽 出する . 続いて , 形態素解析ツールを利用して問題文を 単語に分割した後, 係り受けの情報に基づいて単語のブ ロックを構成する .このブロックと解法式の数值パラメー タを比較し, 問題文からオブジェクトとプロパティを抽 出する .ここでは, ブロックがある数值パラメータと同値 の数字を含む場合, ブロック中の数字が係る助数詞をプ ロパティ,ブロックに含まれる名詞がオブジェクトとして 抽出される.この処理では, 複数の候補が存在してシス テムが自力て解決できない場合, 抽出する単語の決定を ユーザに委ねる. 光して, 問題文に含まれる動詞の抽出 を行い，この動詞を辞書データベースで検索し，产の上 位概念を問題状況とする . 抽出する動詞の決定はユーザ に委ねられ，システム自身は候補をリストアップするの みに留まる. 文章題の問題文は, 短い文章と限られた単 語によって構成されることが多いため，このような表現 でも問題状況の分類はある程度可能であると考えられる が, 複数通りに解釈できる状況はユーザの判断に全面的 に依存するなど，問題もある．問題状況の解釈と表現は， 自然言語処理と常識推論を伴う困難な問題であり，今後 検討すべき課題である.

続いて , システムは未解決の情報がないかチェックし， ユーザに確認のフィードバックを行う . 未解決の情報と は, 問題文に含まれるが, テーブルに抽出されなかった 数字や, テーブルに抽出されているが, 問題文に含まれ ない数値である . 未解決の情報がある場合 , システムは これをリストアップして，ユーザに問題データの修正 · 追加を要求する . また , システムの知識ベースに含まれ ない単語か抽出された場合, 概念辞書を検索して兴の単 語の情報を取り出し, ユーザに単語に対する助数詞など， 常識知識を補間してもらつた上で, 知識ベースに新たな 単語知識として格納する . 図 3 に, 問題データの登録の 実行例を示す . 图 3 では, システムが未解決の情報を提 示し，ユーザか情報の追加を行っている．以上の処理を 通じて, 表 1 や表 2 に示したような問題データが生成さ れる.

最後に , システムはユーザが入力した問題文のテキス トから, 抽出したオブジェクト, プロパティ, 数值パラ メータをスロットとして抜き出し, 問題文テンプレート を生成して問題データに付加する . 問題文テンプレート は, 将来の問題生成において同じ問題パターンの問題が 


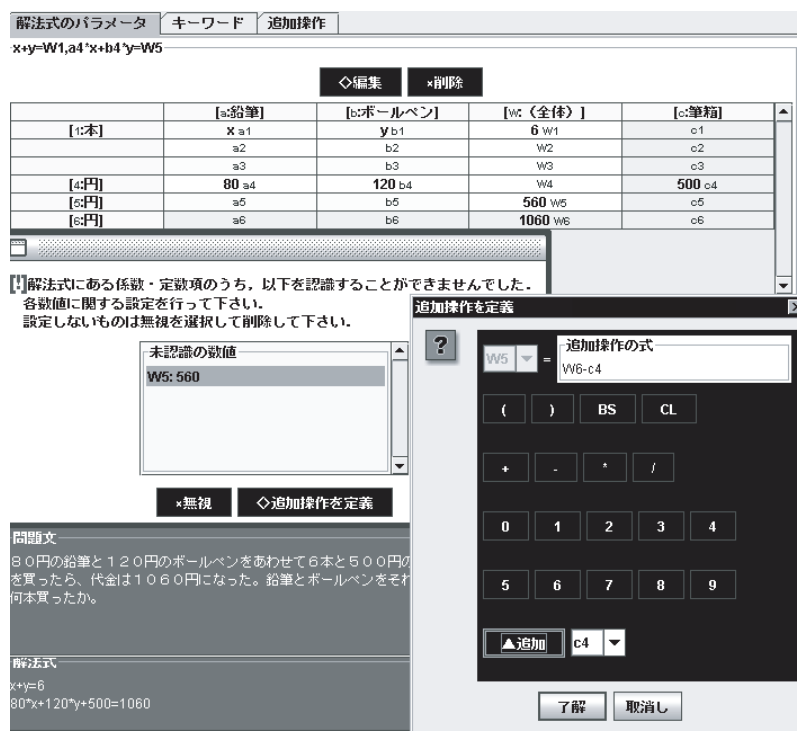

図 3 問題データ登録の画面の一部

生成された場合, 兴の問題文の生成に利用される。

$\S 2$ 作問エピソードの作成

作問エピソードは,システムに登録されている問題デー タのセットから, ユーザが base と newInstance とする問 題を選択すると，プロダクションエンジンが自動的に作 成する . 作問エピソードは, base と newInstance のセッ 卜に対し,プロダクションエンジンが書き換えアクション 生成ルールを用いて 2 つの問題間の特徵を比較し，どの 特徵をどう書き換えるかの手続き (書き換えアクション) を賦与することで作成される．書き換えアクション生成 ルールは, base と newInstance の間て特徵值が異なるか を調べる調査ルール, 調査ルールの結果に基づいて書き 換えアクションを賦与する賦与ルールの 2 種類から成る . 例えば, 表 1 の問題を base，表 2 の問題を newInstance とする作問エピソードの作成を行う場合, プロダクショ ンエンジンは, 調査ルールによりオブジェクトが同一で あるという結果を得て, 賦与ルールによりオブジェクト を兴のままコピーする書き換えアクションを生成すると いった手順で, 表 3 に示すような書き換えアクションを 賦与することになる.このことから，作問エピソードは， 適切な作問が成り立つような書き換えアクションのセッ 卜を生成するための制約である，ということができる．

書き換えアクションは, base と newInstance の間の共 通する特徴, 異なる特徵に基づいて賦与されるものであ り，2つの問題の間の関係とみなすことができる . しか し, base と newInstance の間に共通点が全くない場合 は,どのような inputに対しても newInstance のコピー を output として出力するだけの作問エピソードが作成 されることになる . 従って , 作問エピソードは , どのよ うな問題の組み合わせでも有効というわけではなく，適 切な関係を結ぶことができる問題の組み合わせのみから 作成される .ここで適切な関係とみなされるのは, 先に
表 3 書き換えアクションの例

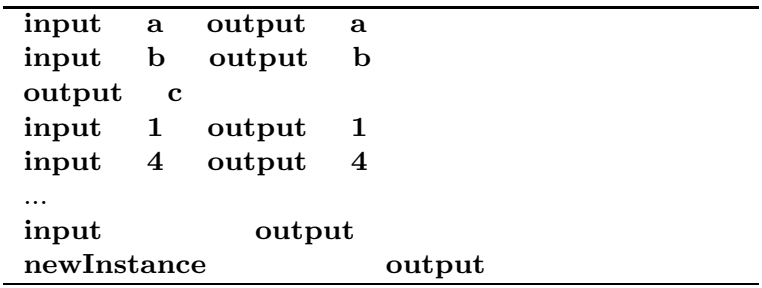

も述べたとおり，問題状況が同一である問題の組み合わ せである

\section{$\S 3$ 新しい問題の生成}

本システムによる問題の生成は, 作問エピソードを利 用して，与えられる問題 input から新しい問題 output の生成を行う，という形式で実行される．作問エピソー ドを利用した問題生成の概念図は，図 1 に示した通りで ある。

先に述べた通り，作問エピソードには書き換えアクショ ンか賦与されている . inputが与えられると, システムは 作問エピソードがinputに適用可能であるかを判断し，可 能であれば書き換えアクションを実行することで, output の問題データを生成する . 作問エピソードが input に適 用可能であるかどうかは, base と input の間の特徵を比 較し，両者の解法構造が同一である場合に可能と判断さ れる.この解法構造は，解法式の標準形と追加操作のセッ 卜によって規定されており，解法を導出するための計算 手続きが全て等しい場合に同一となる．なお，割合は演 算上特殊な性質を持つため，この判定においては，割合 を含む問題と含まない問題とでは構造構造が異なると判 断する補助ルールを使用している . 問題生成の実行方法 には, (1) ユーザが input とする問題を指定し, システム が適用可能な作問エピソードを検索する場合と，(2) ユー ザが使用する作問エピソードを指定し , システムがinput とする問題を検索する場合の 2 通りがあるが，いずれの 場合も，適用可能な全ての組み合わせの問題生成が実行 される。

最後に , 問題文のテンプレートに output のキーワード をあてはめることで output の問題文を生成し, output は新しい問題として出力される.変更生成の場合，ここ で使用するテンプレートは, 問題データベースから検索 して得られる.一方, 新規生成の場合は, 利用できる問題 文テンプレートが存在しないため, システムは問題デー タから「抽象テンプレート」を作成し，仮の問題文を生 成する．これは， $x+y=W_{1}$ に対して「 $\mathrm{a} と \mathrm{~b}$ の合計 はW1 1 1 というように, 式の形式ごとに用意されて いるテンプレートの断片を組み合わせ, 光れを問題デー タの特徵值に応じて変形することで生成される.ユーザ は抽象テンプレートから仮に作成された問題文を参照し ながら，問題文を作成して入力する．システムはユーザ が入力した問題文から問題文テンプレートを生成し，こ れ以降の問題文の生成の際に利用する . 


\begin{tabular}{|c|c|c|c|c|c|}
\hline & \multicolumn{4}{|c|}{ オブジェクト } \\
\hline & & a:バス & b:電車 & W：(全体) & c: (?) \\
\hline \multirow{5}{*}{$\begin{array}{l}\text { プ } \\
\text { 口 } \\
\text { パ } \\
\text { テ } \\
1\end{array}$} & \multirow{5}{*}{$\begin{array}{l}\text { 1:時間 } \\
2: \\
3: \\
4: \mathrm{k} \mathrm{m} \\
5: \mathrm{k} \mathrm{m} \\
6: \mathrm{k} \mathrm{m} \\
\end{array}$} & $x$ & $y$ & $W_{1}$ & \\
\hline & & & & & \\
\hline & & $a_{4}$ & $b_{4}$ & & $c_{4}$ \\
\hline & & & & $W_{5}$ & \\
\hline & & & & $W_{6}$ & \\
\hline & & 動詞 & 行く & & \\
\hline & & 問題状況 & 往復 & & \\
\hline & & 標準形 & $x+y$ & $W_{1}$ & \\
\hline & & & $a_{4} x-$ & ${ }_{4} y=W_{5}$ & \\
\hline & & 追加操作 & $W_{5}=$ & $V_{6}-c_{4}$ & \\
\hline
\end{tabular}

このプロセスを具体例を用いて示す. 表 1 に示す問題 を base , 表 2 に示す問題を newInstance とする作問エピ ソードを選択して作問を実行した場合，システムは問題 データベースを検索し, base と解法構造が同一である問 題が見つかったら，この作問エピソードを適用する．こ こで, 以下のような問題が見つかったと仮定する .

問題文) A 市からB駅経由で195 k m 離れたC市まで行くのに、 A 市から B 駅までは時速 $50 \mathrm{~km}$ mハバスで、B駅からC市までは時 速 $80 \mathrm{~km}$ 電車で行ったら 3 時間かかった。A市からB駅まで、 B駅からC市までにかかった時間は兴れ何時間か。

解) $\mathrm{A}$ 市から B 駅までを $x$ 時間、B駅から C 市までを $y$ 時間とお くと、

$$
\begin{aligned}
& x+y=3 \\
& 50 x+80 y=195
\end{aligned}
$$

より、 $x=1.5, y=1.5$

すると, システムは表 3 に示した書き換えアクション を実行し，output の問題データを生成する．ここで生成 されるデータは，表 4 に示す通りとなる .これは，表 2 の 問題と, 解法が同一で問題文の状況が異なる問題である.

そして, システムはこの output と同一の問題パター ンの問題を問題データベースから検索し, 問題文テンプ レートの獲得を試みる . 問題パターンが同一と判断され るのは, 問題データにおける状況と, 先述の解法構造の 特徵值が等しい問題である．ここでは output と同一パ ターンの問題が見つからなかったとすると , システムは 新規生成と判断し，問題データから抽象テンプレートを 作成して，以下のような問題文を仮に生成する。

問題文) バスと電車はあわせて $W_{1}$ 時間。

1 時間あたり $a_{4} \mathrm{~km}$ mのバスと 1 時間あたり $b_{4} \mathrm{~km}$ 電車で，あ わせて $W_{5} \mathrm{~km}\left[=W_{6} \mathrm{~km}-c 4 \mathrm{~km}\right]$ 。

バスと電車は乥れ光れ何時間か。

次に , output をユーザに提示するとともに , ユーザに 問題データの修正を要求する*1. ユーザは提示される問 題文と問題データを参照しながら，問題文の編集入力を 行う. 図 4 に，問題データの修正の実行例を示す.この 時, この output (図 4 の画面下のウインドウ・右下の

\footnotetext{
*1 ここでは, $\mathbf{c}$ のオブジェクトの設定と, 問題文の入力を要求 する .
}

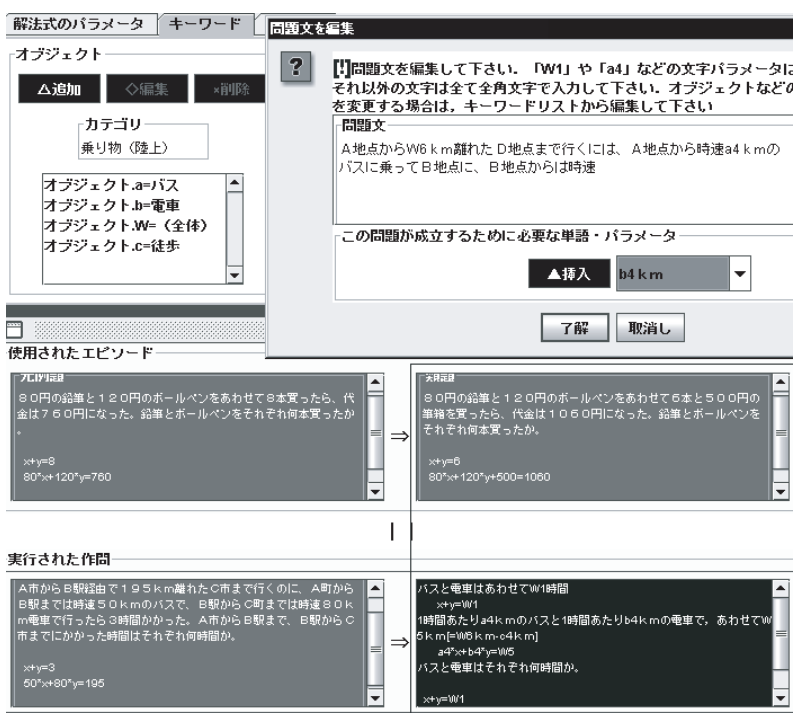

図 4 問題データ修正の画面の一部

フィールドに表示) に対し，乥の生成に使用された作問 エピソードの base (左上) と newInstance (右上), 光 して input (左下) も併せて四項類推の形式で表示され る.以下は, この output の問題文の修正例である .

A 地点から $W_{6} \mathrm{~km}$ 離れた D地点まで行くには、A地点から時速 $a_{4} \mathrm{~km}$ mのバスに乗ってB地点に、B地点からは時速 $b_{4} \mathrm{~km}$ 電車 に乗って、D地点の $c_{4} \mathrm{~km}$ 手前のC地点まで行き、D地点までの 残りは徒歩で行くことになる。バスと電車に合計で $W_{1}$ 時間乗る とすると、バスと電車产れ光れには何時間乗ることになるか。

システムはこの問題文から問題文テンプレートを作成 する．

最後に，ユーザは修正した問題データをシステムに登 録する．このような手続きを踏むため, システムが生成 した問題の中で新たに問題データベースに登録されるの は，ユーザによって評価・修正された問題のみというこ とになる

このように，本システムは類推により，新しい問題の 候補として output を生成してユーザに提示し，ユーザ の知識を引き出すような形式でインタラクションを実行 して, 解法が同一で問題状況が異なる問題を，樣々な解 法の問題に対して生成する

なお, 本システムによる問題生成では, 数値の割り当 ては行われない .これは，本システムの支援対象の想定 が, 問題状況と解法をコントロールして問題を学習者に 提示し, 問題間の比較を行わせる学習であることに基づ いている．ただし，他の学習支援システムへの教材コン テンツ供給を行うためには, 数值の割り当ては重要な問 題であり，今後の課題である .

\section{3. 評 価 実 験}

本システムは, 1. 問題のバリエーションを増殖させ， 適切な問題を生成することができるか，2. 教師ユーザと 
のインタラクションを通じて有効な知識を学習すること ができるか，の 2 点において評価される必要がある．光 のため, 1 の評価を, システムに問題を搭載して機械的 に問題生成を実行させ，生成される問題を評価する「動 作実験」を通じて，2 の評価を実際にユーザに使用して もらい, ユーザとのインタラクションを確認する「運用

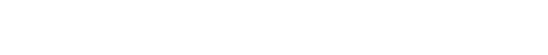

\section{$3 \cdot 1$ 動 作 実 験}

\section{$\S 1$ 方 法}

動作実験は，最初に問題の初期セットをシステムに登 録し, システムに問題生成をさせて教師ユーザとのイン タラクションを行うサイクルを繰り返し実行して, シス テムが生成する問題を評価する，という手続きにおいて 実施した .この問題生成では, 作問エピソードの作成と 問題生成の手続きをシステムに自動実行させた .これは， i) システムに登録されている問題から，関係を結ぶこと が可能な 2 つの問題の組み合わせ全てを選び出して作問 エピソードを生成し，重複するエピソード*2を除外する， ii) i で作成された全ての作問エピソードを適用可能な全 ての問題に適用する，という作業を機械的にシステムに 行わせる方法である．また，本実験における教師ユーザ は，第一著者が行った .

システムに登録する問題の初期セットには, 市販の問 題集 3 冊 $[4,5,6]$ より対象領域の問題を取り出し, 各問 題集の問題からなるセットと，3つのセットをマージし たセットの 4 つを用意した . 表 5 に各初期セットのデー タを示す.

システムが問題のバリェーションを増殖可能であるか どうかは, 問題生成後の問題パターン数の増加率を算出 することで, また , システムが適切な問題を生成可能で あるかどうかは, 生成された問題の問題文の適切さを評 定することで評価を実施する．

\section{$\S 2$ 結 果}

図 5 に, 各初期セットから問題生成を行った後の問題 パターン数の増加率を示す .

問題集 1 からの問題生成では, 新しい問題パターンは 一切生成されていないが, 問題集 2 からの問題生成では， 最終的に問題パターンが倍増している.この結果により， 本システムによる問題生成は, 問題のバリエーションを 増殖させることが可能であることを確認できたが, どの 程度增殖するかは, 問題の初期セットに大きく依存する ことが判明した。

なお，図 5 は問題パターンの増加率を示したものであ

表 5 問題の初期セット

\begin{tabular}{|l|c|c|c|c|}
\hline & 問題集 1 & 問題集 2 & 問題集 3 & マージ \\
\hline 問題数 & 9 & 34 & 34 & 77 \\
問題パターン数 & 6 & 22 & 26 & 41 \\
\hline
\end{tabular}

*2 書き換えアクションのセットが同一であるエピソードである .

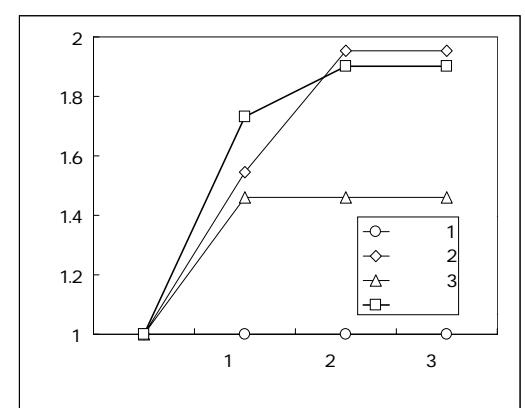

図 5 問題パターン増加率

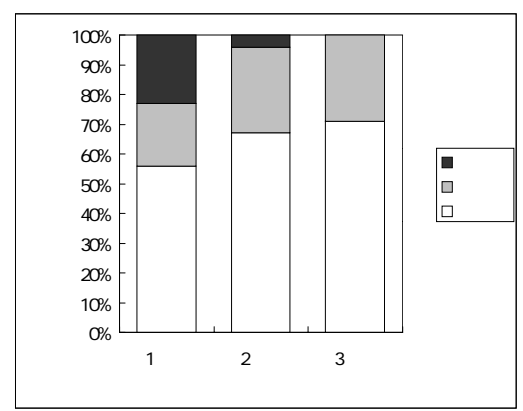

図 6 生成された問題の適切さ

るが, 同一の問題パターンの問題は基本的に複数作成さ れる、例えば，本システムがマージセットから生成した 問題のうち, 同一の問題を除外してカウントしたユニー クな問題の数は, 問題生成の実行 1 回目で 303,2 回目 で 584,3 回目で592 であった .

次に，マージセットからの自動生成によってシステム が生成した問題の適切さを图 6 に示す.図 6 では, シス テムが生成した問題のうち, 変更生成によって問題文を 適切に生成することができた問題（適切），変更生成に よって生成されたが, 問題文に常識知識に基づく部分修 正*3や, 表 4 の c のオブジェクトのように単語知識の入 力をユーザに要求する必要があつた問題 (要修正), 新規 生成によって生成され，ユーザによる問題文の入力が必 要であった問題 (要入力) の, 弚れ光れの占める割合を示 している .なお, 要入力の問題の割合はシステムに算出 させているが, 適切な問題と要修正の問題は, 著者が問 題文を見て判断し，乥の割合を算出している.また，自 動生成によってシステムか提示した問題数は大量であっ たため, 適切な問題と要修正の問題の割合は, 全問題か ら新規生成の問題を除いたセットから 100 問をランダム 抽出し，この 100 問の評定から算出したものである.

図 6 に示されている通り, 問題生成を 2 回繰り返すと, ユーザからの問題文の入力を必要とする問題は出現しな くなる.これは，図 5 にも示されている通り，新規生成の 問題が出現しなくなったためである .この結果から，問

\footnotetext{
*3 例えば,「花屋でジュースを買った」を「店でジュースを買っ た」に「A駅まで船で」を「A港まで船で」に，といった修正 である
} 
題生成と教師ユーザとのインタラクションを繰り返し実 行することで，本システムはある程度適切な問題を生成 することが可能になることが確認された .

\section{$\S 3$ 考 察}

図 5 , 図 6 に示す結果から，本システムは問題のバリ エーションを増殖することが可能であり，ある程度適切 な問題を生成できることか確認できた。

本システムが問題文の生成に使用するテンプレートに は, 問題解決にとって重要でない単語を切り出して变更 することができないという問題点か残っており，ユーザ とのインタラクションによって，常に個々の問題の評価 を受け, 問題文の部分修正を行ってもらう必要性が生じ ている，乥れが，図 6 において，要修正の問題が最後ま で残っている原因である。

また , システムが生成した問題の中には, 通常の教科 書や問題集には載っていないパターンの問題もいくつか 含まれていた .このような問題の例 ${ }^{* 4}$ を示す .

ם output $O$

問題文) $\mathrm{A}$ は $a_{4}$ 円の鉛筆を、Bは $b_{4}$ 円のボールペンを何本か買つ た。二人が使った金額の合計は $W_{1}$ 円で、鉛筆とボールペンの本数 は合計で $W_{5}$ 本であった。A と Bが使った金額は光れ攵れ何円か。

解) $\mathrm{A}$ が使った金額を $x$ 円、B $y$ 円とおくと、

$$
\begin{aligned}
& x+y=W_{1} \ldots \ldots .(1) \\
& \frac{x}{a_{4}}+\frac{y}{b_{4}}=W_{5} \ldots(2)
\end{aligned}
$$

この問題では，鉛筆とボールペン光れ光れの合計の代金 を求める解としており，式 (1) は全体の代金の合計，式 (2) は光れ光れの代金を単価で割って本数を算出するこ とで, 全体の本数の合計を求めている .この問題構造は, 市販の問題集では「速さ・時間・距離」の問題のみが持 つものである .この問題構造を買物という状況に適用す ることによって，新奇な問題か泩成されている .

\section{$3 \cdot 2$ 運 用 実 験}

運用実験では，教師ユーザを募り，本システムの操作 を行ってもらった . 実験 1 では一般大学生に , 実験 2 では 数学専攻の大学院生と高校数学教師に教師ユーザを依頼 して , 本システムがユーザとのインタラクションを通じ て，有効な知識を学習することができるかの確認を行っ た .ここでシステムが学習する知識とは, オブジェクト として使用する単語知識と，問題文テンプレートを作成 するための問題文の 2 つであり，これらをユーザが適切 に供給することが可能かの評価を行う .

\section{$\S 1$ 実験 1}

実験 1 では, 表 6 に示す 2 種類の初期セットをシステ ムに登録した .セット 1 には最も基本的な解法を持つ問 題のみが含まれ，セット 2 には追加操作を持つ複雑な問 題が含まれている

$* 4$ システムが作成した問題文「鉛筆の合計とボールペンの合計 はあわせて $W_{1}$ 円。 1 本あたり $a_{4}$ 円の鉛筆と 1 本あたり $b_{4}$ 円のボールペンで、あわせて $W_{5}$ 本。鉛筆の合計とボールペン
表 6 初期セッ卜 (左：セッ卜 1，右：セッ卜 2)

\begin{tabular}{|cc|ccc||ccc|}
\cline { 3 - 6 } \multicolumn{1}{c|}{} & \multicolumn{3}{c|}{ 解法 } & & \multicolumn{3}{|c|}{ 解法 } \\
状 & 1 & $\mathrm{~A}-1$ & $\mathrm{~B}-1$ & $\mathrm{C}$ & $\mathrm{A}$ & $\mathrm{D}$ & $\mathrm{E}$ \\
\hline 況 & 2 & $\mathrm{~A}-2$ & & $\mathrm{C}-2$ & $\mathrm{D}-1$ & \\
& 3 & $\mathrm{~A}-3$ & & & & & \\
$\mathrm{~A}-2$ & & & \\
$\mathrm{~A}-3$ & & $\mathrm{E}-3$ \\
\hline
\end{tabular}

解法)

$$
\begin{aligned}
& \mathrm{A}: x+y=W_{1}, a_{4} x+b_{4} y=W_{5} \\
& \mathrm{~B}: a_{2} x+b_{2} y=W_{3}, a_{4} x+b_{4} y=W_{5} \\
& \mathrm{C}: x+y=W_{1}, \frac{x}{a_{4}}+\frac{y}{b_{4}}=W_{5} \\
& \mathrm{D}: x+y=W_{1}, a_{4} x+b_{4} y=W_{6}-c_{4} \\
& \mathrm{E}: x+y=W_{1},\left(1+a_{6}\right) x+\left(1+b_{6}\right) y=W_{5}
\end{aligned}
$$

状況)

\section{1:買物 $\quad 2:$ 乗物での移動 $\quad 3:$ 美術館への入館}

表 7 適切な修正を行った参加者数 (左：セット 1 , 右 : セット 2)

\begin{tabular}{|ll|lll||lll|}
\cline { 3 - 6 } \multicolumn{1}{c|}{} & \multicolumn{3}{c|}{ 解法 } & \multicolumn{3}{c|}{ 解法 } \\
\hline 状 & 1 & 9 & 9 & $1^{*}$ & $\mathrm{~A}$ & $\mathrm{D}$ & $\mathrm{E}$ \\
況 & 2 & 9 & $9^{*}$ & 9 & 9 & $5^{*}$ \\
& 3 & 9 & $9^{*}$ & $1^{*}$ & $5^{*}$ & $3^{*}$ \\
& 9 & $6^{*}$ & 9 \\
\hline \multicolumn{2}{|c|}{} \\
\multicolumn{3}{|c|}{ が付加されているセルは新規生成, 無印は変更生成 }
\end{tabular}

この初期セットからシステムに問題生成を実行させる と, システムは 9 つの問題パターンに含まれる問題を各 1 問ずつ，光れ光れのセットごとに合計 9 問を生成して提 示する . 実験参加者には，これらの問題を評価し，シス テムを操作して問題の修正を行うことを課題として依頼 した . 具体的には , システムがオブジェクトの単語を設 定できない場合は，关の単語を与えることを，また，初 期セットに含まれない問題パターンの問題が生成された 場合は，自然な問題文を作成して入力することを求めた . 参加者に対しては, システムの操作に関する説明を充分 に行うとともに, 実験中は常に著者が同席して , システ ムの操作に関する質問に適宜応じた .

実験 1 の参加者は文系の大学 1 年生 18 名で, 弚のうち 9 名にセット 1 を登録したシステム , 残りの 9 名にはセッ 卜 2 を登録したシステムの操作を行ってもらった .なお， 参加者には実験の前に初期セットの問題のうちの 3 題を 練習問題として与えて解かせ, 参加者全員が対象領域の 問題解決能力を持つことを確認した .

\section{$\S 2$ 実験 1 の結果}

表 7 に, 各問題に対して適切な修正を行った参加者数 を示す。

表 7 に示されている通り，変更生成の問題の修正は， セット 1 の参加者 9 名 , セット 2 の参加者 9 名のいずれ も全員が適切に行うことができたが，新規生成の問題の 修正は，適切に行うことができなかった参加者も多く，特 に問題 C-1・C-3 に対しては, 適切な問題文を入力でき た参加者が 1 名のみである.ここで， C-1 は，動作実験 において示した新奇な問題 output $O$ と同一の問題であ るが, 新奇であるために適切な問題文を作成することが

の合計は光れ光れ何円か。」を著者が修正したものである 
できなかった可能性が考えられる．

この結果から，一般の大学生を教師ユーザとした場合， システムか有効な知識を学習できることは確認されなかっ た，光こで, 次の実験 2 では, エキスパートを教師ユー ザとした運用実験を実施する .

\section{$\S 3$ 実験 2}

実験 2 では, この領域のエキスパートして，数学専攻 の大学院生 3 名, および, 現役の高校数学教師 1 名の合 計 4 名が実験に参加した . システムに登録する初期セッ 卜は, 実験 1 におけるセット 1 とセット 2 をマージした セットを用いた . 実験 2 では, システムに問題生成を行 わせた際，新規生成の問題のみを提示するようにシステ ムを設定し , 参加者にシステムを操作して問題の修正を 行うことを課題として依頼した .

\section{$\S 4$ 実験 2 の結果}

実験 2 においては, 参加者全員が全ての問題を適切に 修正することができた .この結果から，領域のエキスパー 卜を教師ユーザとした場合, システムが有効な知識を学 習できることが確認された .

\section{$\S 5$ 考 察}

実験 1 においては, 一般大学生が教師ユーザとなって 本システムとのインタラクションを行ったが , ユーザが 適切な問題修正を行うことができないケースが多くみら れた .このため, 一般大学生とのインタラクションを行っ たシステムは，不適切な知識を獲得し，不適切な問題の 増殖を行ってしまう可能性が考えられる. 実験 2 では，数 学の専門知識を持ち, 数学能力が充分に高いと考えられ る教師ユーザに本システムとのインタラクションを行っ てもらつたが , ユーザは全ての問題を適切に修正した .こ の結果から，本システムが問題生成を実行するためには， 充分な数学能力を持つ教師ユーザが必要であることが判 明した。

\section{4. ま と め}

本研究では, 数学の文章題を対象に, 問題状況と解法 において多樣な問題を生成するシステムの実装を行った . システムの実装にあたっては，1. 作問を事例化した作問 エピソードを利用する , 2. 教師ユーザとのインタラクショ ンを行うという方法を採用して , システムに登録された 問題から新しい問題を生成し，問題のバリエーションを 増殖する機能を実現した .㫕して , 本システムの評価実験 により , 本システムは問題のバリエーションを増殖させる ことが可能であると確認されたものの，弚のためには充 分な能力を持つ教師ユーザが必要であることが分かった .

今後の課題としては, 問題文を生成する機構を強化す ることが挙げられる . 現在のシステムは , 新規生成の問 題の問題文作成は，教師ユーザに全面的に委ねられてい る.評価実験により，文章題の問題文作成は困難であり， ユーザに数学能力が要求されることが判明したため，特
別な能力のないユーザでも利用できるようになるために は, 問題文作成を支援し，問題修正を容易に行うことが できる方法やインタフェースの検討が必要である .

\section{$\diamond$ 参 考 文 献 $\diamond$}

[Chi 81] Michelene T. H. Chi, Paul J. Feltovich, Robert Glaser: Categorization and Representation of Physics Problems by Experts and Novices, Cognitive Science, Vol.5, pp.121-152 (1981).

[Gick 83] Mary L. Gick, Keith J. Holyoak: Schema Induction and Analogical Transfer, Cognitive Psychology, Vol.15, pp.1-38 (1983).

[English 97] Lyn D. English: Children's Reasoning Processes in Classifying and Solving Computational Word Problems, Mathematical Reasoning: Analogies, Metaphors, and Images, Mahwah, NJ: Lawrence Erlbaum Associates, pp.191220 (1997).

[平嶋 92] 平嶋宗, 中村祐一, 池田満, 溝口理一郎, 豊田順一: ITS を指向した問題解決モデル MIPS, 人工知能学会学会誌, Vol.7, No.3, pp.475-486 (1992).

[Hirashima 94] Tukasa Hirashima, Toshitada Niitu, Kentaro Hirose, Akihiro Kashihara, Jun'ichi Toyoda: An Indexing Framework for Adaptive Arrangement of Mechanics Problems for ITS, IEICE Transactions on Information and Systems, Vol.E77-D, No.1, pp.19-26 (1994)

[平嶋 95] 平嶋宗, 東正造, 柏原昭博, 豊田順一: 補助問題の定式 化, 人工知能学会誌, Vol.10, No.3, pp.413-420 (1995)

[平嶋 01] 平嶋宗, 梅田多一, 志岐隆弘, 竹内章: XML を用いた 算数の文章問題の作成・共有環境, 教育システム情報学会誌, Vol.18, No.3, pp.284-296 (2001).

[金西 03] 金西計英, 林賢太郎, 光原弘幸, 矢野米雄: 教材知識に 基づき WBT 上で演習問題を生成する機能の実現, 教育システ 么情報学会誌, Vol.20, No.2, pp.71-82 (2003).

[中野 00] 中野明, 平嶋宗, 竹内章: 「問題を作ることによる学習」 の知的支援環境，電子情報通信学会論文誌，Vol.J83-D-I, No.6, pp.539-549 (2000)

[Novick 88] Laura R. Novick: Analogical Transfer, Problem Similarity, and Expertise, Journal of Experimental Psychology: Learning, Memory, and Cognition, Vol.14, No.3, pp.510-520 (1988)

[白田 04] 白田由香利: 経済最適化問題を例とする数学 Web 教材 自動作成システム, 学習院大学経済論集, Vol.41, No.1 (2004).

[高野 03] 高野敦子, 橋本淳: 知識ベースに基づいた学習者個別 演習問題生成手法について, 情報処理学会研究報告, NL-160, pp.23-28 (2003)

[寺尾 98] 寺尾敦, 楠見孝: 数学的問題解決における転移を促進す る知識獲得について, 教育心理学研究, Vol.46, No.4, pp.472-483 (1998).

[1] MathTeX工房, http://www12.plala.or.jp/htown/mathtex/

[2] 茶筌, http://chasen.naist.jp/hiki/ChaSen/

[3] 分類語彙表, http://www.kokken.go.jp/

[4] 10 分間集中 TRAINING 中学 2 年数学, 数研出版社

[5] ワンランク上の実力をめざす段階別新問題集中学 2 年数学, 教学研究社.

[6]〈もんの中学基礎がため $100 \%$ 中 2 数学計算 ・関数編, くも ん出版.

〔担当委員 : 柏原 昭博〕

2005 年 11 月 11 日 受理 


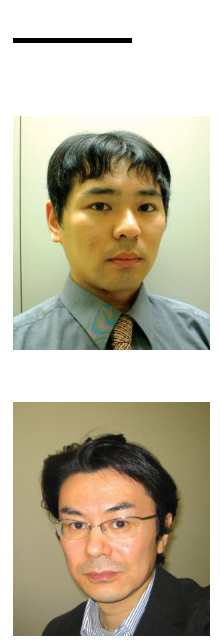

者紹介

小島 一晃(学生会員)

2000 年 名古屋工業大学知能情報システム学科卒業, 2002

年 名古屋大学大学院人間情報学研究科博士前期課程修了, 同大学院博士後期課程進学, 現在に至る. 認知科学, 人工 知能, 教育工学の研究に従事し, 人間の創造的問題解決に 興味を持つ。

\section{三輪 和久(正会員)}

1984 年名古屋大学工学部卒業. 1989 年同大学大学院工学 研究科博士課程修了 (情報工学尃攻). 工学博士.1989 年 同大学情報処理教育センター助手, 1993 年同大学大学院 人間情報学研究科助教授を経て, 2004 年より名古屋大学 大学院情報科学研究科メディア科学専攻教授. 1991 年から 1992 年, 米国 Carnegie Mellon University, Dept of Psychology, visiting assistant professor . 認知 科学, 人工知能, 教育工学の研究に従事.とりわけ, 発見, 創造, 洞察, 協同など, 人間の高次思考過程に興味がある。 